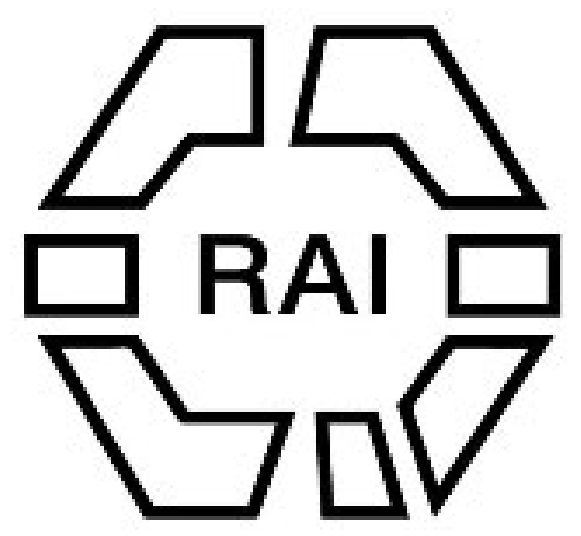

Initiation Ceremonies of Natives of the Papuan Gulf Author(s): J. Holmes

Source: The Tournal of the Anthropological Institute of Great Britain and Ireland, Vol. 32 (Jul. - Dec., 1902), pp. 418-425

Published by: Royal Anthropological Institute of Great Britain and Ireland

Stable URL: http://www.jstor.org/stable/2842829

Accessed: $14 / 06 / 2014$ 12:49

Your use of the JSTOR archive indicates your acceptance of the Terms \& Conditions of Use, available at http://www.jstor.org/page/info/about/policies/terms.jsp

JSTOR is a not-for-profit service that helps scholars, researchers, and students discover, use, and build upon a wide range of content in a trusted digital archive. We use information technology and tools to increase productivity and facilitate new forms of scholarship. For more information about JSTOR, please contact support@jstor.org.

Royal Anthropological Institute of Great Britain and Ireland is collaborating with JSTOR to digitize, preserve and extend access to The Journal of the Anthropological Institute of Great Britain and Ireland. 


\title{
INITIATION CEREMONIES OF NATIVES OF THE PAPUAN GULF.
}

\author{
By Rev. J. Holmes.
}

[Presented November 11th, 1902: With Plate XLI.]

THIS preliminary paper makes no pretence to be an exhaustive study of the initiation ceremonies of all the tribes of the Papuan Gulf. It has reference only to the ceremonies of initiation observed by the tribes living in the district of Elema, the coast territory lying between Cape Possession on the east and the Alele river on the west.

In the quest for information on the customs and ceremonies associated with initiation, as observed by these tribes of the Elema district, one recognizes, only too fully, the manifold difficulties that oppose a successful and absolutely accurate version of what initiation means to the initiated savage, and a just appreciation of the inner meaning of the ceremonies attendant thereto.

To him initiation is all-important. On the performance of the instructions he received as an initiate the social and moral welfare of his tribe depends; as an individual he is only a unit of his tribe, but as such he must always conduct himself in all things for the highest interests of his tribe. The knowledge he acquired when an initiate must ever be to him a sacred possession, and not be imparted to the uninitiated; although on all topics outside initiation he is communicative, and never happier than when he can give information to inquirers after knowledge. He knows a great deal about the mammals, birds, reptiles, fishes, trees, shrubs, and plants of his district, and all these he will freely discuss and their respective value to him and his people; but approach him on the topic of initiation and he immediately becomes sullen and silent; over that period of his life a veil is drawn, and he resents any attempt on the part of the uninitiated to draw it aside to peer within.

Having to combat such rigid reticence on the part of those who have it in their power to make known in detail the ceremonies of initiation, it is evident that much of the information we have obtained will be open to corrections as our knowledge of these tribes advances.

An effort will be made in this paper to state the stages of initiation in the sequence observed by the initiates. It must, however, be remembered that the names given by the outsider to, the respective stages, are not in every case the same as those used by the initiates, neither are these names common to all the tribes of Elema. 
The various stages of initiation are marked by feasts given by the relatives of initiates, and the most important item in these feasts is the native pig. Unless the father or male guardian ${ }^{1}$ of the boy who is being initiated provides a pig for each stage in the boy's initiation, the boy is marked henceforth as not having been fully initiated; this is a serious matter to him when he becomes a man, and debars him from many privileges as well as lays him open to many a taunt and insult from his compeers.

A small boy from birth until he reaches the age of about ten years, is said to be a siare; after the age of about ten years, he is said to be siare sora until he enters the eravo for initiation. During this period, and when he is about the age of five years, the first step toward his initiation is taken by his father or male guardian, who prepares what may be termed a dedicatory feast and known by the Moreaipi tribe as the meauleave feast. The object of this feast is to give the father or male guardian an opportunity to declare to the relatives of the family in particular, and the tribe in general, that he purposes, at the proper time, to have the boy, in whose honour the feast is given, fully initiated as a nember of the tribe. This feast is purely a family affair; pigs are killed, large quantities of food are cooked, and great attention is given to the distribution of the food, so that the maternal relatives of the boy being dedicated may have a very ample share of the food. This distribution of the food to the maternal relatives of the boys has important significance; it intimates to them that in future the father or male guardian of the boy will have the boy as his sole charge. Further, it is a declaration to the tribe, that the father or male guardian, by this public act, becomes responsible for all the fees, in pigs and other kinds of food, that will be demanded as the boy passes through the respective stages of his initiation.

After this feast the boy spends more of his time with his father than hitherto, when he was the special charge of his mother; he now has his head shorn or shaven completely, with the exception of two little tufts, one on the crown, the other about an inch behind the forehead.

When the boy reaches the age of ten years and is known as siare sora, he proceeds to the eravo in which he is to be secluded for an indefinite period, which is short or long as he develops' quickly or otherwise; he now learns that he is about to take a very important step in his life's history, for within a short time he will be introduced to the mountain god, Kovave.

On entering the eravo for the period of seclusion, the boys, hitherto known as siare sora, become known collectively as malai-asu, while individually they are called heava among themselves, and as such they are now allowed to grow their hair, to oil their bodies, and, generally, to assume those kinds of ornaments that belong to the stage they have recently reached. Almost simultaneously with their becoming heava, the forerunners of the mountain god Kovave appear in the village in the

1 On the death of the father one of his brothers acts as guardian to his orphan nephew.

${ }^{3}$ This is the large men's house, which has been termed club-house or temple by various writers. 
form of a number of young men wearing conical masks, painted in grotesque designs of human faces, and draped with long grasses reaching down to the knees of the wearers. The arrival of the forerunners of Kovave in the village is a serious matter to the females, young and old, also to the uninitiated male members of the tribe. Amongst the latter are boys or men who are of illegitimate birth, and who, therefore, are not eligible for initiation. The masked men are supposed to be sacred: formerly it was permitted to them to kill anyone who tried to identify them, providing the curious one was a woman or an uninitiated man. Not only is their person considered sacred; it is claimed for these messengers of Kovave that they too, are gods ; and, as proof of their deity, the native sage remarks that they do not need to walk on the soles of their feet as mortals have to do, but that they hop about as is characteristic of gods.

On the arrival in the village of these messengers of Kovave, the drums are beaten and the conch-shells are sounded as a warning, to the uninitiated, of the presence of the gods in the village.

For a period of about ten days these masked men prance about the village; for a like period, every night after sunset, the whining of bull-roarers, interspersed with much beating of the drums in the eravo, and an occasional march through the village, keep all the women and children in their houses in a state of terror lest some great evil may befall them if they wander abroad and are seen by any of Kovave's representatives.

During this period of about ten days, the women are constantly reminded by their husbands and male friends of the importance of having an abundance of food in readiness for Kovave when he arrives. When the food is all ready, a greater noise than usual is made in the village the night before the assumed arrival of the mountain god himself. In the early morning, as soon as the sun has risen, the men rush out from the eravo, armed with bows and arrows, and shoot the pigs that have previously been brought together in readiness for slaughter. These are quickly quartered, and hung on poles in front of the eravo in which the new initiates are secluded. Near this eravo are cross-poles on which the women hang the food (sago, banana, fish, betel nuts; etc.), as their contribution to the feast to be given to Kovave.

Long before noon, the messengers of Kovave come into the village from the bush to announce the arrival of Kovave, and to request that they may be laden with food to take to him to appease his hunger. The old men now step forward and give the portions of food to Kovave's representatives, who prance away with it toward the bush, and continue to do so until all the food is taken to the bush. All things for the feast of Kovave are by this time in readiness in the bush, and the place is tabooed to the women, children, and uninitiated members of the tribe. As soon as night sets in and the village is in darkness, the novicesnow known as malai-asu or heava-are formed into Indian file and marched into the bush, where Kovave is supposed to be staying.

Each boy is accompanied by his father or male guardian, who stands by him 
until he is acknowledged by the mountain god, and returns with him to the eravo, that there he may impress upon him the importance of what he has experienced in the bush.

On arrival of the boys in the bush, it is so dark that they are unable to see anyone, but presently they are addressed by a feigned voice, that they cannot recognize, but are informed it is Kovave speaking to them.

He promises them to become their friend, as long as they keep all secrets in connection with their initiation, but if they divulge these secrets to the uninitiated, he will punish them with disease and death.

After this injunccion to absolute secrecy, each boy, quite unexpectedly, has a mask placed on his head, by someone standing behind him, and this being done, the boys in company with their father or respective male guardians, are marched back in Indian file to the eravo, wearing the masks, supposed to have been given to them by Kovave as a guarantee of his good fellowship. So far as the boys are concerned, thus ends their part in the feast of Kovave; all the food that has been taken to the bush is eaten by their male relatives, and the initiated members of their tribe. As heava, they have to settle down to seclusion within the eravo, until they are qualified to pass on to the next stage in their initiation.

The reasons assigned for this period of seclusion are, that when boys reach the age of puberty, they ought not to be exposed to the rays of the sun, lest they suffer thereby; they must not do heavy manual work, or their physical development will be stopped, all possibility of mixing with females must be avoided, lest they become immoral, or illegitimacy become common in the tribe. The provisions made to assist the boys to keep in seclusion are ample.

On becoming heava, they take up permanent residence in the eravo in which they are to pass through the respective stages of their initiation. This is a large building, provided with an entrance in front and an exit at the back. When the boys are in seclusion as heava, in the eravo, a platform is carried out some distance from the exit, and part of this platform is closely fenced in that the boys can come out and sit down in the open air and not be seen by passers-by. The unenclosed part of the platform is used by the mothers or female kin of the heava, as a convenient place on which to put the food, when they bring it to their sons or relatives in seclusion. That all possibility of the boy talking to the mother, or of seeing her when she comes with the food be avoided, she has to cough or make some distinctive noise, that the boy may know of her approach and retire to the interior of the eravo until she has placed the food on the platform and returned to the village, when the boy is free to go out and get the food through the fence.

Seclusion does not mean complete incarceration; for the boys are allowed to go out of doors occasionally and get fresh air; but on such occasions they are encased in plaited coconut palm leaves, which they carry from within, so that only their feet are exposed. During these walks in the open they are under a bond of silence; in the eravo they can talk as much as they like among themselves, but when out of doors 
for exercise, they must not speak to one another, neither must they converse with anyone they may pass; they must avoid going near to their homes, and the possibility of being recognized by their female relatives.

If there are arbitrary rules to be observed in connection with the period of seclusion, the taboo on certain kinds of food is no less arbitrary to the initiates. There are many kinds of food that must not be eaten by the heava; chief among these are certain fish, as tauara, toai, teave and milura. The initiates are told that if they eat any food that is tabooed, they will speedily become bald and prematurely shrivelled in body; disease and death will come upon them, and their names will be held in disgrace among their relatives. Whilst observing the taboo of certain kinds of food, in the period of their seclusion, they are instructed by the old man who resides constantly with them as their instructor and adviser, in all matters pertaining to taboo recognized by their tribe. They learn the seasons that are closed against certain kinds of fish, and the times when certain kinds of food and fruit are to be reserved for coming feasts; so that when they leave the eravo they are quite qualified in such matters to look after their own property and to care for the best interests of their tribe.

The occupations of the heava, during their confinement in the eravo, are, of necessity, few, and take the form of pastimes rather than work of a serious and important nature. Plaiting armlets and girdles, preparing paper mulberry for si's, or genital coverings such as are worn by the men, making combs and headdresses for future use, are the principal forms of work indulged in to break up the monotony of their secluded life. It is during this period that they receive such information as is calculated to equip them for all the duties and obligations of citizens and worthy members of their tribe. From their guardian they receive all kinds of advice respecting their duty to their tribe; this must always take the first place in all their actions; the enemies of the tribe must be the enemy of the individual initiate; it will be to the best interests of the tribe that it should be so. In selecting a wife, the first thing to be considered is the interests of the tribe, whether she is likely to bear healthy children; on the other hand, if she proves to be barren, the obligation of the husband to his wife ceases, because she cannot bear him children, i.e., because she is not contributing to the strength of the tribe. Whatever serves the highest interests of the tribe is justifiable; if a woman bears twins, it is right to bury one of the twins, because no mother is thought to be capable of nourishing at the same time two children as successfully as she can one. Two weak men are not the credit to the tribe that one strong man can be : hence, until quite recently, infanticide was taught and practised as being essential to the future interests of the tribe.

Their conception of right and wrong is governed by what public opinion requires in order that the tribe may maintain its position among other tribes.

It is an open question if illicit intercourse per se is punishable and to be avoided on the ground of being immoral ; it is certainly detrimental to the welfare of the tribe, and that is sufficient reason for checking it as far as possible. No one will 
be responsible for the future conduct of one illegitimately born, and for that reason it is not murder to kill an illegitimate child by strangulation.

There are many reasons given why a child must not be allowed to live if its birth cost its mother her life; the chief is, that every life given has to be avenged; an eye for an eye is an immutable law with the savages of Elema. The deceased mother is not supposed to have died of natural causes, or of senile decay; in some way the child took her life and that is said to be ample reason why the child should be buried alive in the grave of its dead mother. A more important consideration is the fact that the mother being dead, there is no one that can be relied on to nourish the child satisfactorily that it may become an useful unit of the tribe.

The Gulf Papuan believes implicitly in the survival of the fittest. Personal desires, likes and dislikes, everything that is, or can be, must be subordinated to the pursuit of obtaining the fittest. This idea is innate in him, it is fostered by his guardians when he is a child, it is inculcated in his initiation, it is dominant in him until he dies.

Sorcery is an important element in the life of the tribes of Elema, and the guardian, whose person is sacred during the period of initiation of the boys, proceeds much as follows, in giving them instruction in the art of sorcery; not with a view of making them sorcerers, but to impress on their minds how great is the power of sorcerers. He proceeds in this way. He squats on the floor of the eravo, and the boys squat around him. Having provided himself with a hollow bamboo containing herbs used by sorcerers, the chief of which are upe, the ginger root, and aputa, a herb brought down from the mountains. These he places before the boys, at the same time informing them that each herb inside the bamboo, if used in a certain way, has power to cause sickness, disease, storms and death. Having taken out all the herbs in the bamboo, he proceeds to name each one, and describes its respective power and how it is used; this being done, he returns the herbs to the bamboo, arranging at the same time that it be taken to the top of a coconut tree and lashed to the fai, that is, the young palm leaf not yet expanded. It remains there until the fai begins to burst its covering and unfold itself in frond-like form, when it is brought back to the eravo. The boys are assembled and the old man tells them he has reason to punish a certain individual of an adjoining village, but avoids naming as his victim any relative of the boys present. He then gives the boys a pot of water and instructions to boil the water and keep it boiling; having placed the sorcerer's bamboo, with the herbs in it, on the rack erected over the fireplace, he leaves the boys for a time. On his return to the eravo he pretends to be annoyed that the boys in his absence have not observed his instructions fully; after an expression of annoyance and a considerable display of concern, evidently with a view of impressing on the boys the importance of what he is about to do, he proceeds to take from the bamboo certain herbs, and places them in the boiling water. The herbs having remained in the boiling water for some time, during which period the old man indulges in unintelligible incantations, he takes 
the pot of boiling herbs outside the eravo, and buries its contents. On his return to the boys, he tells them they must wait for results, but grumblingly adds, that if there are no results, it will be owing to their negligence in failing to keep the water boiling.

The succeeding stage to heava is known as heapu, and when the boys enter upon this period of their initiation a feast is given by their relatives, termed helei by the Toaripians, probably because it is generally celebrated at the season of the year known as heleikelei. On reaching the heapu stage of their initiation, the period of absolute seclusion terminates; this however by no means allows them freedom to mix with their relatives in the village, or to sleep at home. They are now free to don the regulation ornaments of the heapu, made by themselves during the period of seclusion; they are also at liberty to appear in public, but under strict surveillance. They can take an airing daily in the vicinity of the village, and when invitations come to them from friendly villages, to come and share in a feast, they can accept them and go; but on all occasions when they leave the eravo as heapu, an initiated member of the tribe accompanies them, to see that they do not commit a breach of initiation rules. On these occasions when they appear in public, if it be merely for outdoor exercise, or when going on a visit to a friendly village, they go out in numbers, are all adorned alike with headdresses, armshells, neck ornaments, and carry either clubs or bows and arrows. At this period the lads wear plain belts covered with oil and red clay, these they tie very tightly round their waists. The carved wooden belts, so characteristic of the Papuan Gulf, are not worn till the next stage has been attained. During the heapu period of initiation, the initiates occasionally meet the semese or fighting men of the tribe, from whom they receive every incentive to become warriors.

There are certain tests that each heapu has to pass, before he can be considered as eligible to become a semese or warrior. Of these the most important tests are, chewing upe (the root of the ginger plant), and drinking the urine of the semese chief. The significance of observing these tests has not yet been ascertained; that much importance is attached to the latter is evident at times when a complaint is brought against the influence of the foreigner as undermining all the old customs and nullifying them by new teaching. It is not uncommon to hear an old chief remark, "I drank my chief's urine, but no one has drunk mine."

Such initiates as undergo this test lie on their backs with open mouths, the chief whose right it is stands over them and micturates into the mouths waiting to receive his urine; an initiate who successfully passes this stage is recommended to the warriors as eligible and ready to enter upon his last stage of initiation. On becoming semese the initiate has to make the acquaintance of the mysteries of tiparu; this is deemed the greatest privilege, and for it another feast has to be given by the initiates who have become semese. The tiparu (Pl. XLI, 1), or bullroarer, is common in the Papuan Gulf, but so far as can be ascertained, it is not supposed in itself to possess any supernatural power, and is only used as a visible expression of a malignant god or deity, said to reside on Yule Island. 
It may have a greater influence on the social life of the tribe who keep it than is yet known by outsiders; it certainly has the power of terrorising the women and children, beyond that it is not yet evident what further significance it may have.

There is a legend of considerable length concerning the origin of tiparu and how it first came into the Papuan Gulf, but as it has no particular connection with initiation, it can be omitted from this paper.

What the initiates, who have reached the semese stage, learn at the feast given by their relatives to tiparu, is disappointing to them, as they have often admitted. On the occasion of this feast, they are taken away from the village to some lonely place in the bush, and on their arrival there the only thing to be seen is a display of clever manipulation of the bull-roarer, so as to produce almost every possible kind of whining. They are allowed to share in the feast, which is frequently interspersed with the whining of the bull-roarer; and they are taught how to produce these sounds from the bull-roarer; but, above all things, they are bound to absolute secrecy.

To divulge the mysteries of tiparu to any female of the tribe, i.e., to let it be known among the women that the whining of the bull-roarers is not the cry of a god but the work of a man, is to bring upon the indiscreet the curse of tiparu, which is equivalent io death, and any woman found anywhere near the place where the feast of tiparu is being celebrated is taken and made the common property of all the men assembled there; to be released, later, with the warning that if she divulges what has taken place, to any female, she will be put to death.

Semese is the last obligatory stage of initiation; having become a semese, there is no further need for the initiate to reside in the eravo, he is now free to marry and make a home for himself.

There are many ceremonies attendant to initiation as observed by the tribes of Elema that are not mentioned in this paper, because it is desirable to acquire further knowledge of them; what is herein given must be accepted as preliminary, for it is evident that the sacred regard of these tribes for initiation indicates a consciousness of its importance to them, as yet not quite intelligible to the uninitiated who would peer into their realm of barbarous sophistry.

\section{Explanation of Plate XLI.}

Fig. 1.-This drawing is a fac-simile of the most valued bull-roarer, tiparu, of the Moreaipi tribe, who live at Orokolo in the Gulf of Papua. The figures are supposed to represent the original male and female ancestors of this tribe, who are named Iva and Ukaipu respectively. The Moreaipi claim a common ancestry for all the tribes of the Elema district from Iva and Ukaipu. Iva is said to have sprung from the ground like a plant. Ukaipu was found by Iva in the hollow trunk of a large tree.

Fig. 2.-Dance Belt, representing Iva and Ukaipu : Moreaipi tribe.

Figs. 3 \& 4.-Rain Gods.

Figs. 5 \& 6.-Orokolo Men. 